\title{
Effect of Supplementation of Different Forms of Selenium on In Vitro Dry Matter Digestibility and Microbial Biomass Production
}

\author{
Sarang Vajpeyee ${ }^{1}$, Jayabalan Ramesh ${ }^{1}$, Raman Karunakaran ${ }^{1}$ and Jagannathan Muralidharan ${ }^{2}$ \\ ${ }^{1}$ Department of Animal Nutrition, Madras Veterinary College, TANUVAS, Chennai, Tamil Nadu, INDIA \\ ${ }^{2}$ Mecheri Sheep Research Station, Pottaneri, Salem, Tamil Nadu, INDIA \\ "Corresponding author:J Ramesh; E-mail: rameshnutrition@gmail.com
}

Received: 22 March, 2021

Revised: 29 March, 2021

Accepted: 02 April, 2021

\begin{abstract}
Nano selenium was synthesized by wet chemical method at laboratory level. In this study particle size, particle shape, zeta potential and selenium content were characterized by using particle size analyser (PSA) and inductively coupled plasma mass spectrometry (ICP-MS). The result revealed that selenium nano particle is spherical in shape with mean particle size of $31.8 \pm$ 2.31 nano meter $(\mathrm{nm})$ and concentration of selenium is $98.34 \pm 2.8$ per cent selenium that ensured the purity of nano selenium. The toxicity was analysed by MTT assay against Vero cell line. The nano selenium effectively inhibited the growth of Vero cells in a dose dependent manner. In vitro digestibility and microbial biomass production also evaluated on different form of selenium on basal diet at different levels. We used sodium selenite, selenocysteine and nano selenium. Based on the calculations, $\mathrm{IC}_{50}$ for nano selenium derived from selenium powder was $89.11 \mu \mathrm{g} / \mathrm{ml}$. when selenium is added at graded level to the basal diet in any form resulted in significant increase $(\mathrm{P}<0.05)$ in digestibility parameter such as in vitro apparent dry matter digestibility, in vitro true dry matter digestibility and microbial biomass production at all levels of addition compared to when no selenium was added. From the results it can be inferred that spherical shaped, nano-selenium particles of size ranging $31.8 \mathrm{~nm}$ could be produced by wet chemical method at laboratory level.
\end{abstract}

\section{HIGHLIGHTS}

(0 Nano selenium can be produced by wet chemical method at laboratory level.

(0 Nano selenium has all the required properties and safe to use.

Keywords: Nano selenium, In vitro digestibility, Microbial biomass, Particle size

Selenium is an essential trace element for animal health, immune function, productivity, and reproductive performance in farm animals and found in both organic and inorganic forms in nature, has a specific place among the nutrients in animal feed because of its role in animal body (Mehdi and Dufrasne, 2016).

Selenium added to the feeding ration is not fully utilized by the animal's organism, as its significant part is absorbed and metabolized by ruminal bacteria, thus the highest selenium concentrations are found in ruminal biomass, whereas the lowest are in the ruminal fluid (Panev et al., 2013).In ruminants, inorganic Se compounds are partly reduced by ruminal microbes to unabsorbable elemental selenium resulting in a lower Se apparent absorption. Selenoamino acids are subject to ruminal microbial degradation also decreasing apparent selenium absorption from the digestive tract. Rumen microorganisms have been shown to incorporate Se from both inorganic and organic forms into their own protein and into the microbial cell wall components.

Faixova et al. (2016) concluded that feeding diets

How to cite this article: Vajpeyee, S., Ramesh, J., Karunakaran, R. and Muralidharan, J. (2021). Effect of supplementation of different forms of Selenium on in vitro dry matter digestibility and microbial biomass production. J. Anim. Res., 11(2): 305-309. Source of Support: None; Conflict of Interest: None 
supplemented with selenium from organic or inorganic sources significantly increased the Se concentrations in the total rumen fluid and blood. Shahid et al. (2020) showed that dietary selenium yeast supplementation improved ruminal fermentation pattern, induced ruminal epithelial growth and increased GSH-Px activity in ruminal epithelium of goats.

So, keeping all this point in mind this experiment was carried out to assess the effect of different selenium sources on microbial biomass production and in vitro digestibility with the objective of arriving for optimum dose of different selenium in animal trial.

\section{MATERIAL AND METHODS}

\section{Nano selenium synthesis}

Nano Se was prepared using sodium selenite and ascorbic acid according to the modified method of Qian Le et al. (2010). Finally, the gray precipitant obtained was filtered and washed by water and ethanol, respectively.

\section{Characterization of nano selenium}

When the particle size is reduced to nano size, the properties of the materials are likely to be far different from the bulk materials. In the present study, Transmission electron microscopy, particle size analyser, and inductively coupled plasma mass spectrometry were used to analyse the properties like morphology, particle size distribution etc.

\section{In vitro cytotoxicity assay}

In vitro cytotoxicity assay was carried out in vero cell lines to ensure the safety of nano particle source of selenium as per the method of Mosmann, 1983. The parameters like per cent cell inhibition exhibited under different concentration of nano forms of selenium was studied.

\section{In vitro dry matter digestibility}

The rumen liquor needed for the experiment was collected in slaughter house from six sheep immediately prior to slaughter and brought to the laboratory by maintaining the temperature of rumen liquor at $39{ }^{\circ} \mathrm{C}$ and under anaerobic condition during the transit. Ruminal fluid was filtered through 4 layers of muslin cloth and stored in pre warmed thermos container at $39^{\circ} \mathrm{C}$ till its use.

The basal diet used for the experiment had roughage: concentrate in the ratio of 60:40. Roughage used in this study was Bajra Napier hybrid grass $\left(\mathrm{CO}_{4}\right)$. The concentrate mixture had maize (48.8 per cent), Soya bean oilcake (21.6 per cent) de oiled rice bran (25.6 per cent), salt ( 1.6 per cent) and calcite ( 2.4 per cent). The roughage component was ground to pass through $1.0 \mathrm{~mm}$ sieve. The roughage: concentrate mixture was well mixed to form the basal diet. There is also addition of sodium selenite, nano selenium and selenocysteine at different levels.

The accurately weighed individual feed ingredients were subjected to in vitro gas production studies. $500 \mathrm{mg}$ of feed in $40 \mathrm{ml}$ of buffered rumen fluid were incubated in prewarmed $\left(40^{\circ} \mathrm{C}\right) 100 \mathrm{ml}$ calibrated glass syringes placed in an incubator as described by Menke et al. (1979).

An incubation period of $24 \mathrm{~h}$ was adopted for this study. At the end of the incubation, in vitro apparent dry matter digestibility (IVADMD), in vitro true dry matter digestibility (IVTDMD) and microbial biomass production were determined.

In vitro apparent digestibility of dry matter (IVADM) was determined as per Blummel et al. $\left(1997_{\mathrm{b}}\right)$. True digestibility was calculated as the weight of substrate incubated minus the weight of the residue after neutral detergent solution treatment.

The microbial biomass was calculated using the equation quoted by Blummel et al. (1997 ${ }_{\mathrm{a}}$ ).

Microbial biomass $=$ Substrate truly digested - Substrate apparently digested

\section{STATISTICAL ANALYSIS}

All the data were statistically analysed with analysis of variance (ANOVA) through the procedure of statistical analysis system (IBM SPSS version 22.0 for windows) as per Snedecor and Cochran (1989).

\section{RESULTS AND DISCUSSION}

\section{Nano selenium}

The size and zeta potential of nano particle synthesized 
from sodium selenite is $31.8 \pm 2.31 \mathrm{~nm}$ and $-33.1 \pm 6.5$ $\mathrm{mV}$ respectively while product yield is $40.97 \%$. The synthesized nano selenium powder contains $98.62 \%$ selenium, free from impurities, nano in nature and spherical in shape. Result is presented in table 1.

Table 1: Product yield (recovery \%), particle size, zeta potential and selenium content in nano form of selenium (Mean* \pm SE)

\begin{tabular}{lll}
\hline Sl. No. & Characterization parameters \\
\hline 1 & Chemical name of source & Sodium selenite \\
2 & Recovery (\%) & $40.97 \pm 0.79$ \\
4 & Size (assessed through particle & $31.8 \pm 2.31$ \\
& size analyser) nm* & \\
5 & Zeta potential (mV) & $-33.1 \pm 6.50$ \\
6 & Selenium content (\%) & $98.34 \pm 2.80$ \\
7 & Shape & Spherical \\
\hline
\end{tabular}

*Mean of six observations

Similarly, Zhang et al. (2017) synthesized nano selenium with mean particle size of $36.8 \pm 4.1 \mathrm{~nm}$ using beta lactoglobulin as a stabilizer in redox system of ascorbic acid and selenite. Gangadoo et al. (2017) use solution phase synthesis approach for selenium nanoparticles by reducing selenium tetrachloride in the presence of ascorbic acid. Nanoparticle spherical in shape and have size $46 \mathrm{~nm}$.

\section{In vitro cytotoxicity assay}

In order to determine safe level of inclusion of nano selenium, in vitro cytotoxicity test was done on in vero cell line with concentrations, $0.25,0.5,1,2,5,10,20,30$, $40,50,60,70,80,90,100 \mu \mathrm{g} / \mathrm{ml}$ for nano selenium. Based on the calculations, $\mathrm{IC}_{50}$ for nano selenium derived from selenium powder was $89.11 \mu \mathrm{g} / \mathrm{ml}$. The $\mathrm{IC}_{50}$ is defined as the sample concentration that is required to reduce the absorbance to half that of the control and which would give the $50 \%$ cell death. Since our inclusion level of nano selenium is $0.3 \mathrm{mg} / \mathrm{kg}$ and it revealed that the nano selenium is safe up to the level of $30 \mathrm{mg} / \mathrm{kg}$ to use as feed supplement as source of selenium in lamb ration.

Hashem et al. (2021) showed that IC50 of mycosynthesized Se-NPs was $316.73 \mu \mathrm{g} / \mathrm{ml}$ towards Vero cell line CCL-81. Salem et al. (2020) showed that $\mathrm{IC}_{50}$ value of selenium nanoparticle against two different cell cultures, namely; human normal lung fibroblast (Wi 38) and human cancer colorectal adenocarcinoma epithelial (Caco-2) was 171.8 and $104.3 \mu \mathrm{g} / \mathrm{ml}$ respectively,

\section{In vitro dry matter digestibility}

The results of the in vitro studies to assess effect of different forms of selenium on in vitro dry matter degradability (IVDMD) are presented in the table 2. From the results it can be inferred that when selenium is added at graded level to the basal diet in any form (inorganic, organic and nano) resulted in significant increase $(p<0.05)$ in digestibility parameter such as in vitro apparent dry matter digestibility, in vitro true dry matter digestibility and microbial biomass production at all levels of addition compared to when no selenium was added. Rumen fermentation is a fundamental and special process of the ruminant metabolism and it determines the assimilation and intake of nutrients from ingested food.

Table 2: Effect of supplementing different forms of selenium at graded levels in basal diet on in vitro apparent dry matter digestibility, in vitro true dry matter digestibility and microbial biomass production by In Vitro Gas Production Technique $\left(\mathrm{Mean}^{*} \pm \mathrm{SE}\right)$

\begin{tabular}{llllll}
\hline \multicolumn{7}{c}{ IVADMD \% } & IVTDMD \% & $\begin{array}{l}\text { Microbial } \\
\text { biomass \% }\end{array}$ & SEM & $\begin{array}{l}\text { P } \\
\text { Value }\end{array}$ \\
\hline Control & $29.67 \pm 1.44^{\mathrm{a}}$ & $37.20 \pm 1.56^{\mathrm{a}}$ & $7.53 \pm 0.13^{\mathrm{a}}$ & 1.21 & 0.21 \\
\hline Inorganic selenium (ppm) & & & \\
\hline 0.150 & $35.27 \pm 1.73^{\mathrm{ab}}$ & $55.06 \pm 1.51^{\mathrm{b}}$ & $19.80 \pm 2.51^{\mathrm{b}}$ & 1.43 & 0.04 \\
0.225 & $35.47 \pm 2.21^{\mathrm{ab}}$ & $55.80 \pm 2.12^{\mathrm{b}}$ & $20.33 \pm 3.09^{\mathrm{b}}$ & 2.41 & 0.046 \\
0.300 & $35.60 \pm 1.20^{\mathrm{ab}}$ & $56.00 \pm 2.89^{\mathrm{b}}$ & $20.40 \pm 1.86^{\mathrm{b}}$ & 2.52 & 0.049 \\
0.375 & $36.00 \pm 2.30^{\mathrm{b}}$ & $56.53 \pm 1.79^{\mathrm{b}}$ & $20.53 \pm 3.80^{\mathrm{b}}$ & 1.45 & 0.023 \\
0.450 & $37.00 \pm 1.73^{\mathrm{b}}$ & $56.27 \pm 2.08^{\mathrm{b}}$ & $19.27 \pm 0.37^{\mathrm{b}}$ & 1.80 & 0.03 \\
\hline Organic selenium (ppm) & & & & \\
\hline 0.150 & $37.20 \pm 1.27^{\mathrm{b}}$ & $55.267 \pm 2.87^{\mathrm{b}}$ & $18.07 \pm 4.00^{\mathrm{b}}$ & 2.34 & 0.025 \\
0.225 & $37.80 \pm 1.33^{\mathrm{b}}$ & $56.07 \pm 3.12^{\mathrm{b}}$ & $18.27 \pm 3.06^{\mathrm{b}}$ & 2.21 & 0.045 \\
0.300 & $37.90 \pm 1.67^{\mathrm{b}}$ & $56.47 \pm 4.22^{\mathrm{b}}$ & $18.57 \pm 5.88^{\mathrm{b}}$ & 1.54 & 0.035 \\
0.375 & $37.40 \pm 0.87^{\mathrm{b}}$ & $57.10 \pm 2.89^{\mathrm{b}}$ & $19.70 \pm 3.76^{\mathrm{b}}$ & 2.10 & 0.041 \\
0.450 & $38.00 \pm 0.91^{\mathrm{b}}$ & $56.67 \pm 2.33^{\mathrm{b}}$ & $18.67 \pm 3.17^{\mathrm{b}}$ & 1.76 & 0.040 \\
\hline Nano selenium (ppm) & & & & \\
\hline 0.150 & $37.80 \pm 0.58^{\mathrm{b}}$ & $56.33 \pm 3.84^{\mathrm{b}}$ & $18.53 \pm 3.88^{\mathrm{b}}$ & 2.54 & 0.034 \\
0.225 & $38.00 \pm 0.42^{\mathrm{b}}$ & $57.17 \pm 2.80^{\mathrm{b}}$ & $19.17 \pm 2.24^{\mathrm{b}}$ & 1.34 & 0.042 \\
0.300 & $38.20 \pm 0.42^{\mathrm{b}}$ & $57.73 \pm 3.70^{\mathrm{b}}$ & $19.53 \pm 3.81^{\mathrm{b}}$ & 1.88 & 0.02 \\
0.375 & $38.60 \pm 0.42^{\mathrm{b}}$ & $58.67 \pm 2.33^{\mathrm{b}}$ & $20.07 \pm 2.19^{\mathrm{b}}$ & 1.11 & 0.033 \\
0.450 & $39.00 \pm 1.15^{\mathrm{b}}$ & $57.67 \pm 4.10^{\mathrm{b}}$ & $18.67 \pm 2.96^{\mathrm{b}}$ & 0.67 & 0.044 \\
\hline
\end{tabular}

Means with different superscripts within a column differ significantly $(\mathrm{p}<0.05) ; *$ Mean of six observations. 
In this trial, Inorganic, Organic and Nano selenium at graded levels when added to basal diet significantly $(\mathrm{p}<0.05)$ increased in vitro apparent dry matter digestibility, in vitro true dry matter digestibility and microbial biomass production at all levels of addition compared to unsupplemented group.

Consistent with our result Shi et al. (2011) stated that addition of nano selenium to the basal diet of sheep significantly $(p<0.001)$ increased the feed utilization and rumen fermentation pattern through improvement in nutrient digestibility, whereas Ibrahim et al. (2018) reported that Nano selenium supplementation at $0.3 \mathrm{mg} /$ $\mathrm{kg}$ level improved nutrient digestibility, feeding value and growth performance in ossimi lambs compared to Sodium selenite and Selenium yeast form of supplementation.

\section{CONCLUSION}

The result of the present study indicated that spherical shaped, nano-selenium particles of size ranging $31.8 \mathrm{~nm}$ could be produced by wet chemical method at laboratory level. Based on the calculations, $\mathrm{IC}_{50}$ for nano selenium derived from selenium powder was $89.11 \mu \mathrm{g} / \mathrm{ml}$. All the forms (Inorganic, Organic and Nano) of selenium supplementation resulted in significantly higher in vitro apparent dry matter digestibility (IVADMD), in vitro true dry matter digestibility (IVTDMD) and microbial biomass production compared to control. Hence, thus synthesized selenium nano particles could be used as a feed supplement for lambs as per the standard recommended dosage $(0.3 \mathrm{mg} / \mathrm{kg}$ of feed NRC, 2007 recommendation).

\section{ACKNOWLEDGEMENTS}

The authors very much grateful to authorities of Tamil Nadu Veterinary and Animal Sciences University Chennai for providing necessary facilities to carry out this research study.

\section{REFERENCES}

Blummel, M., Makkar, H.P.S. and Becker, K. 1997a. In vitro gas production: a technique revisited. J. Anim. Physiol. Anim. Nutr., 77: 24-34.

Blummel, M., Makkar, H.P.S., Chisanga, G., Mtimuni, J. and Becker, K.1997. The production of dry matter intake of temperature and tropical roughages from in vitro digestibility/ gas production of African roughage in relation to ruminant live weight gain. Anim. Feed. Sci. Technol., 69: 131-141.

Faixová, Z., Piesova, E. Makova, Z. Cobanova, K. and Faix, S. 2016. Effect of dietary supplementation with seleniumenriched yeast or sodium selenite on ruminal enzyme activities and blood chemistry in sheep. Acta Veterinaria Brno., 85(2): 185-194.

Gangadoo, S., Stanley, D. Hughes, R. Moore, R.J. and Chapman, J. 2017. The synthesis and characterisation of highly stable and reproducible selenium nanoparticles. Inorg. Nano-Met. Chem., 47(11): 1568-1576.

Hashem, A.H., Khalil, A.M.A. Reyad, A.M. and Salem, S.S. 2021. Biomedical applications of mycosynthesized selenium nanoparticles using penicillium expansum ATTC 36200. Biol. Trace Elem. Res., 1: 11.

Ibrahim, E.M. and Mohamed, M.Y. 2018. Effect of different dietary selenium sources supplementation on nutrient digestibility, productive performance and some serum biochemical indices in sheep. Egyptian Journal of Nutrition and Feeds, 21(1): 53-64.

Kargar Razi, M., Sarraf Maamoury, R. and Banihashemi, S. 2011. Preparation of nano selenium particles by water solution phase method from industrial dust. Int. J. Nanodimens., 1(4): 261-267.

Mehdi, Y. and Dufrasne, I. 2016. Selenium in cattle: A review. Molecules, 21: 545.

Menke, H., Raab, L. Salewski, A. Steigass, H. Fritz, D. and Schneider, W. 1979. The estimation of digestibility and metabolizable energy content of ruminant feeding stuffs from the gas production when there are incubated with rumen liquor in vitro. J. Agric. Sci., 93: 217-222.

Mosmann, T. 1983. Rapid calorimetric assay for cellular growth and survival: Application to proliferation and cytotoxicity assays. J. Immuno Methods., 65: 55-63.

NRC. 2007. Nutrient Requirements of Dairy Cattle. 9th Ed. National Academy Press, Washington, DC, USA.

Panev, A., Hauptmanova, K. Pavlata, L. Pechova, A. Filípek, J. and Dvorak, R. 2013. Effect of supplementation of various selenium forms and doses on selected parameters of ruminal fluid and blood in sheep. Czech J. Anim. Sci., 58: 37-46.

Qian, Li, Chen, T. and Yang, F. 2010. Facile and controllable one step fabrication of selenium nano particles assisted by L- cysteine. Mater. Lett., 64: 614 -617.

Salem, S.S., Fouda, M.M. Fouda, A. Awad, M.A. Al-Olayan, E.M. Allam, A.A. and Shaheen, T.I. 2020. Antibacterial, cytotoxicity and larvicidal activity of green synthesized selenium nanoparticles using Penicillium corylophilum. $J$. Cluster Sci., 1: 11. 
Shahid, A.B., Malhi, M., Soomro, S.A., Shah, M.G., Kalhoro, N.H., Kaka, A., Mal, R., Soomro, M.A., Samo S.P. and Sanjrani, M.N. 2020. Influence of Dietary Selenium Yeast Supplementation on Fermentation Pattern, Papillae Morphology and Antioxidant Status in Rumen of Goat. Pak. J. Zool., 52(2): 565.

Shi, L., Xun, W., Yue, W., Zhang, C., Ren, Y., Liu, Q., Wang, Q. and Shi, L. 2011. Effect of elemental nano-selenium on feed digestibility, rumen fermentation, and purine derivatives in sheep. Anim. Feed Sci. Tech., 163: 136-142.

Snedecor, G.W. and Cochran, W.C. 1989. Statistical Methods, $8^{\text {th }}$ edn., Iowa State University Press, Ames, Iowa.
Van Ryssen, J.B. and Schroeder, G.E. 2003. Effect of heat processing of protein sources on the disappearance of their selenium from mobile bag in the digestive tract of dairy cows. Anim. Feed Sci. Technol., 107: 15-27.

Zhang, W., Zhang, J., Ding, D., Zhang, L., Muehlmann, L.A., Deng, S.E., Wang, X. and Li, W. 2017. Synthesis and antioxidant properties of Lycium barbarum polysaccharides capped selenium nanoparticles using tea extract. Artificial Cells, Nanomed. Biotechnol., 46(7): 1463-1470. 
